\title{
EFFECT OF SOIL pH ON THE ANTHOCYANIN LEVEL OF HORTENSIA (Hydrangea macrophylla)
}

\author{
Muhammad Rifai Hariri'1, Maulana Safril Yusuf 1 , Lulut Dwi Nurmamulyosari², \\ and Anastya Eka Kharisma ${ }^{3}$ \\ ${ }^{1}$ Postgraduate Student of Biology Department, Faculty of Mathematics and Natural Sciences \\ Institut Pertanian Bogor \\ ${ }^{2}$ Postgraduate Student of Biology Department, Postgraduate Programme Universitas Brawijaya \\ ${ }^{3}$ Postgraduate Student of Biology Education Programme, Postgraduate School Universitas Negeri Malang \\ Correspondence author: muhammadrifqihariri@gmail.com
}

\begin{abstract}
Anthocyanin is a natural pigment that can express red, blue, and purple color. It can be accumulated in leaves, thorn, tuber, fruit, flower, and seed. Hortensia (Hydrangea macrophylla) known as 'Panca Warna', is a plant that can express different sepal colour due to environmental factor such as soil $\mathrm{pH}$. The objective of this study was to determine the effect of three different soil $\mathrm{pH}$ on the level of anthocyanin pigment in the sepal of Hortensia. This research was a descriptive quantitative which used randomized block design with nine replications. Seven kind of anthocyanin was measured using differential pH spectroscopy method and analyzed using One-Way ANOVA. The result revealed that the three different soil pH did not affect the anthocyanin level among the measured samples.
\end{abstract}

Keywords : soil pH, anthocyanin level, Hortensia (Hydrangea macrophylla)

\section{INTRODUCTION}

Anthocyanin is one of popular natural pigment which can express different colour like orange, red, blue, and purple (Gross, 1987). The pigment plays an important role in determining the fruit or vegetable's color quality and so far it is only known as red and purple pigments in plants, whereas it can be used as a fairly high antioxidant. Wang et al. (1997) found a positive correlation between antioxidant activity and its levels on some kind of anthocyanidins like cyanidin, delphinidin, malvidin, peonidin, and pelargonidin. Flowers and fruits generally contain a mixture of simple anthocyanin consisting of one kind of anthocyanidins such as Passion fruit, Petunia and Pelagornium flowers. Pear contains two kinds of anthocyanidins and some types of wines contain more than 20 kinds.

Hortensia, part of the genus Hydrangea and family Pyraloidea with number of members of as many as 80 species is commonly known in Indonesia as Kembang Bokor, Kembang Tiga Bulan, and Panca Warna. It has small and clustered inflorescence shaped sepals with varies color from white, blue, purple, to red (Scrutiny, 2000; Gardens, 2006; Ahqafi, 2011). The roots can be used for the treatment of kidney stone disease although has not been scientifically proven. Anthocyanin pigments extracted from fruits such as grape skin has been used as a coloring agent in soft drinks products, sour milk, alcoholic beverages, and frozen food products. Hessayon (2009) mentioned that there are a variety monomeric anthocyanin pigment in Hortensia sepal that causing petal color assortment. The pigments can be used as a natural dye due to its flower blooming throughout the year and can be obtained easily because it can grow easy to thrive in various climates conditions. 


\section{MATERIALS AND METHODS}

\section{Soil pH Measurement}

The soil pH measurement was performed using soil tester.

\section{Anthocyanin Extraction and Measurement}

The sepal was washed in flowing water for three minutes then dried using tissue paper. The anthocyanin was extracted using $0,1 \%$ Methanolic- $\mathrm{HCl}$ and measured using differentialpH spectroscopy method based on Giusti and Wrolstad (2001). The measurement was using $3 \mathrm{ml}$ extract and was diluted into $7 \mathrm{ml} \mathrm{KCl}$ buffer solution $\mathrm{pH} 1$ for the first mesurement and $7 \mathrm{ml} \mathrm{CH}_{3} \mathrm{COONa} \mathrm{pH} \mathrm{4,5for} \mathrm{the} \mathrm{second} \mathrm{measurement.} \mathrm{Each} \mathrm{monomeric} \mathrm{pigment} \mathrm{was}$ measured twice, using different maximum wavelength $\left(\lambda_{\text {vis-max }}\right.$ listed on Table 1 below) and $700 \mathrm{~nm}$.

Table 1. $\lambda_{\text {vis-max }}$ for each measured anthocyanin monomeric

\begin{tabular}{|l|c|}
\hline Anthocyanin monomeric & $\boldsymbol{\lambda}_{\text {vis-max }}$ \\
\hline Cyanidin-3-galactoside & 530 \\
\hline Malvidin-3-glucoside & 538 \\
\hline Pelargonidin & 524 \\
\hline Pelargonidin -3-glucoside & 508 \\
\hline Pelargonidin -3-sophoroside-5-glucoside & 506 \\
\hline Peonidin-3-glucoside & 536 \\
\hline Petunidin-3-glucoside & 546 \\
\hline
\end{tabular}

\section{Statistical Analysis}

The optical density value was measured using formula listed below and analyzed using One-Way Anova with $p<0,05$.

$$
A=\left(A \lambda_{\text {vis-max }}-A_{700}\right)_{\mathrm{pH} 1,0}-\left(A \lambda_{\text {vis-max }}-A_{700}\right)_{\mathrm{pH} 4,5}
$$

Monomeric pigment $(\mathrm{mg} / \mathrm{l})=\frac{\mathrm{A} \times \mathrm{MW} \times \mathrm{DF} \times 1000}{\varepsilon \times \mathrm{L}}$

\section{RESULT AND DISCUSSION}

The total anthocyanin pigment indicated that $\mathrm{pH} 6.5,6.7$, and 6.8 were $5.184 \mathrm{mg} / \mathrm{L}$, $4.004 \mathrm{mg} / \mathrm{L}$ and $4.648 \mathrm{mg} / \mathrm{L}$ respectively. Based on the statistical analysis, it is known that there was no effect of soil pH to the anthocyanin levels on Hortensia (see Figure 1).

Anthocyanins are unstable molecules and very easily degraded. The stability of anthocyanins are influenced by $\mathrm{pH}$, temperature, light, oxygen, the structure and concentration of anthocyanins, as well as the presence of other components such as flavonoids, protein, and minerals. The degradation rates increased during the process of extraction and storage with the increasing temperature. The rise in temperature (thermal degradation) induces loss of anthocyanins' glycosyl cluster by glycoside bond hydrolysis. The thermal degradation causes the formation of chalcone that causes loss of anthocyanin color (Rein, 2005).

Basen on the results of statistical analysis, the levels of monomeric anthocyanin pigment in three different soil $\mathrm{pH}$ were not significantly different. It can be caused of the influence of soil pH value which was ranged from 6.5 to 6.8 and the irradiation to the plants. 


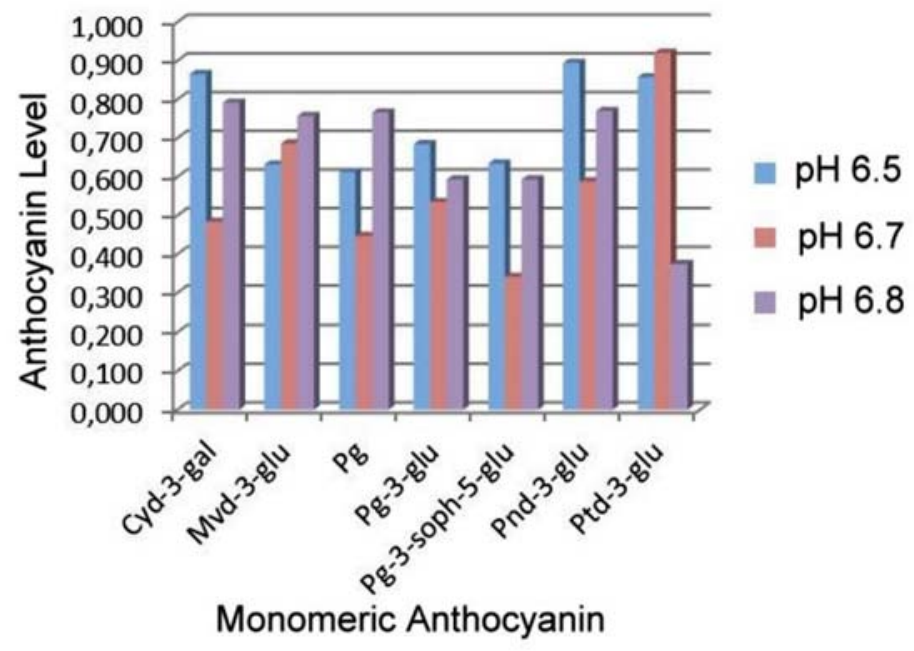

Figure 1: Anthocyanin monomeric pigment level comparison among three different soil $\mathrm{pH}$.

Schenectady (2008), states that Hortensia would be better if planted and placed in a slightly shaded and not exposed to a direct sunlight during flowering will cause bleaching and the flower colours will fade.

Halcomb \& Sandra (2010) reports that the acidic soil pH range (4.5 to 5.5), expressed blue colour. In the range 6-7, the colour is pink, whereas in the range 5.5 to 6.5 , it can be pink, light blue, light purple, or a mixture of these colours on the same sepals (see Figure 2). Wade (2009) reports that the mechanism of colour variations on Hortensia can be affected by the presence of aluminum and iron. Aluminum and iron that accumulates in the cells of Hydrangea's sepal can form a more stable colour complex.

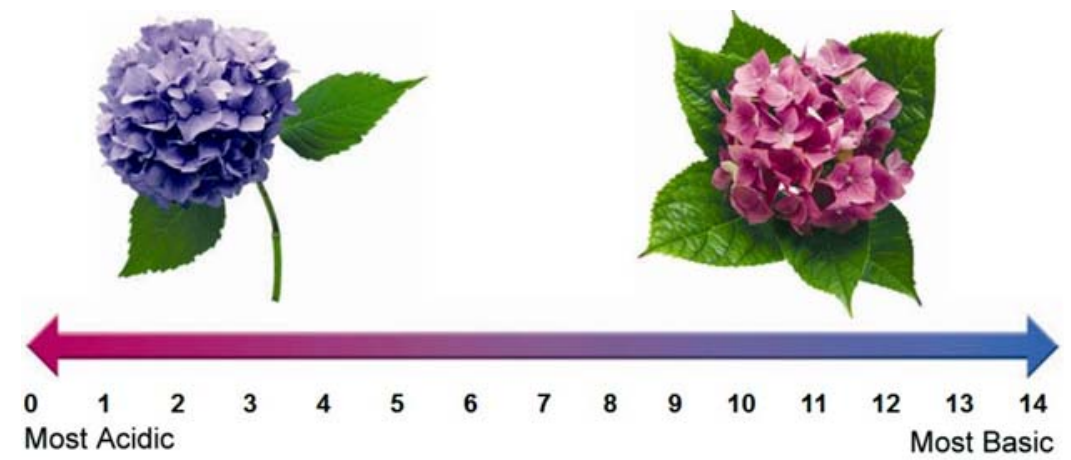

Figure 2: Colour change on Hortensia's sepal due to different soil pH (Heisdorffer, 2012).

The soil $\mathrm{pH}$ value can affect the availability of aluminum. In the range of $\mathrm{pH} 5$ to 6.5 aluminum is available and can be absorbed easily but at $\mathrm{pH}$ more than 6.5 aluminum is not available and affects the sepal's colour change. If there is enough aluminum accumulates in the sepal's cells, the colour will be blue whereas if there is no or only slight accumulation of aluminum, the anthocyanin will binds to the iron the sepal colour will be pink (Heisdorffer, 2012). Based on the data and reference, the three different soil $\mathrm{pH}$ did not not affect the levels of anthocyanin pigment due to the soil pH range was not slightly different. 


\section{CONCLUSION}

The anthocyanin total pigment level in $\mathrm{pH} 6.5,6.7$, and 6.8 were $5.184 \mathrm{mg} / \mathrm{L}, 4.004 \mathrm{mg} /$ $\mathrm{L}$, and $4.648 \mathrm{mg} / \mathrm{L}$ respectively and there was no significant level differences among them.

\section{REFERENCE}

Ahqafi. 2011. Stabilization of Anthocyanin. http://www.scribd.com/doc/16769033/ Stabilization-of-Anthocyanin.

Gardens, F. 2006. Hydrangea Species \& Varieties. www.farmingtongardens.com.

Giusti, M., and R. E. Wrolstad. 2001. Characterization and Measurement of Anthocyanins by UV-Visible Spectroscopy. Current Protocols in Food Analytical Chemistry. John Wiley \& Sons, Inc

Gross, J. 1987. Pigments in Fruits. London: Academic Press.

Halcomb, M., and R. Sandra. 2010. Hydrangea Production. United States: University of Tennessee

Heisdorffer, A. M. 2012. Hydrangeas with a Past and a Future. Kentucky: Daviess County Extension Agent.

Hessayon, D. G. 2009. Hydrangea. www.superfloralretailing.com.

Rein, M. 2005. Copigmentation Reactions and Color Stability of Berry Anthocyanins. University of Helsinki Department of Applied Chemistry and Microbiology Food Chemistry Division

Schenectady. 2008. Hydrangea as a Houseplant. New York: Cornell University.

Scrutiny. 2000. Hydrangea macrophylla (Bigleaf Hydrangea). http://zipcodezoo.com/Plants/ H/Hydrangea_macrophylla/.

Wade, G. L. 2009. Growing Bigleaf Hydrangea. United State: The University of Georgia and Ft. Valley State College.

Wang, H., G. Cao, and R. L. Prior. 1997. Oxygen Radical Absorbing Capacity of Anthocyanins. J. Agric. Food Chem. 45 (2):304-309. 